\title{
The specificity of developing and implementing different models of occupational health services
}

DOI: $\underline{\text { http://doi.org/10.26758/7.1.6 }}$

Alina Ferdohleb

PI State Medical and Pharmaceutical University "Nicolae Testemițanu”, Chișinău, Republic of Moldova; National Centre of Public Health; Scientific laboratory "Occupational Health"

Address correspondence to: Alina Ferdohleb, Scientific laboratory "Occupational Health", National Centre of Public Health, 67 A, Gh. Asachi, Str., Chișinău, Postal code MD-2028, Republic of Moldova. Ph.: +373-79-402597; E-mail: alina.ferdohleb@gmail.com; aferdohleb@cnsp.md

\begin{abstract}
Objectives. We performed the analytical study of occupational health services system implementation's specificity and highlighted the particularities of different occupational health services in European countries caused by decentralization, short-term hiring, high mobility of human resources, implementation of new technologies and work processes.

Organization and performance of the system of occupational health services have become a difficult assignment because of the decentralized national economy, short-term employment contracts, the high mobility of human resources, implementation of new technologies and new working methods.

Material and methods. This work is the result of organized research and meta-analysis of 31 systematic reviews provided with the logistical support of the World Health Organization, the International Labour Organization, Council of Europe, Institute of Occupational Health in Finland and other international organizations; it is important to mention that none of them explicitly defined the management problem and Occupational Health Services model for the Eastern Europe \& postSoviet regions, between 1998 and 2014.

Results. The basic occupational health services' system (BOHS) is essential in protecting people's health at their workplaces, their wealth, and work capacity, as well as in preventing work accidents. BOHS should be approachable for any employee fair, efficient, cost-effective, and guaranteed by the public authorities. ILO/WHO started to shape Global Public health policy by launching the "Health for All" strategy in 1977. This strategy spelled out the key target for a global health policy for the rest of the 20th century as follows: "by the year 2000 all people in all countries should have a level of health that will permit them to lead a socially and economically productive life". In 2003-2005, the Committee on Occupational Safety and Health of ILO called for the development of Occupational Health Services as part of the National Program for Occupational Safety and Health, emphasizing that the development of occupational health services is a component of the National Occupational Safety and Health System. Likewise, the BOHS was recognized as a step towards implementing ILO Conventions no 161 (1985) and the new ILO Global Strategy on Safety and Health at Work, which were adopted by the $92^{\text {nd }}$ ILO conference in 2004.

Conclusions. Training human resources in the field, producing professionals, is the fundamental condition for ensuring quality and performance of this service. In addition, WHO/ILO have developed different occupational health services models depending on the health systems.
\end{abstract}


Keywords: Basic Occupational Health Services; International Labour Organization; World Health Organization; Convention no. 161 (1985).

\section{Introduction}

According to WHO, from a total of about 130 million employees working in Europe, only $50 \%$ are covered by Occupational Health Services (OHS), which means that about 65 million do not have access to the OHS (Rantanen, 1999). The coverage of these services varies from $25 \%$ to $95 \%$ among the workforce in different countries. It should be said that only official employees enter the statistics, whereas freelancers and housewives are not included. Considering this, the unofficial coverage level is even lower. In the globalizing world, the development of occupational health services has not been all that impressive covering only $15 \%$ of the worldwide workforce. The workers most in need in small-scale enterprises, micro enterprises, agriculture and informal sector do not have access to occupational health services. The objective of Occupational Health for All set in the WHO Global Strategy on Occupational Health in 1995 has not got much closer in the past 15 years (Rantanen, 2009).

There were adopted numerous directives related to occupational safety and health, working conditions and other documents about employees' social safety in the last 50 years in Europe.

Occupational health services (OHS) concept was built and developed through globalization of the work market. OHS strategy includes maintaining a healthy and safe working environment, protecting health and preservation of working capacity and active participation of employees and managers in the process of developing workplaces.

International Labor Organization (ILO) Convention no. 161 from 1985 and its recommendations no. 171 are essential instruments in developing and organization of basic occupational health services (BOHS) for employees from different branches of national economy.

ILO's conventions and European Commission's directives provide a comprehensive approach to preventing occupational diseases and promoting equity and accessibility of the services. However, these documents allow the existence of different BOHS systems and models.

\section{Materials and methods}

This work is the result of organized research and meta-analysis of 31 systematic reviews published between 1998 and 2014, with the logistical support of the World Health Organization, the International Labour Organization, Council of Europe, Institute of Occupational Health in Finland and other international organizations. The bibliographical and case study methods were used to collect and analyze information from reports and official documentation of the National Centre for Public Health, along with literature in the field from European countries over the 1998-2014 period.

This meta-analysis work was based on "Survey of the Quality and Effectiveness of Occupational Health Services in the European Union and Norway and Switzerland" funded by SALTSA (The Joint Programmer for Working Life Research in Europe) and organized as a collaborative effort between the National Institute for Working Life (NIWL) of Sweden and the Finnish Institute of Occupational Health (FIOH). The project was organized by the Research and Development Centre for Occupational Health Services so that it had a project group in Helsinki and Kuopio, Finland, 2001 year (FIOH, 2011).

This survey was of particular interest to us as it had experts from the participating countries, and representatives of ILO, WHO/Euro, and the European Agency for Safety and Health at Work (Bilbao), and the European Trade Union Confederation assigned. 
The main objectives of the survey were to determine what indicators were used to measure the impact of OHS in 17 European countries (Austria, Belgium, Denmark, Finland, France, Germany, Greece, Ireland, Italy, Luxembourg, the Netherlands, Norway, Portugal, Spain, Sweden, Switzerland and the United Kingdom). Persons were appointed from different countries to act as national collaborators for the survey. These persons supported and organized interviews and offered their insight and views about OHS and quality management in their respective countries. Most of them were from research institutes, universities and professional organizations already experienced in OHS research.

OHS units received a questionnaire with mostly open-ended questions. Depending on the country, the questionnaire was translated into the local language by the national collaborator and sent to pre-selected persons in OHS units by e-mail or mail. The interviewer also met $50 \%$ of all OHS unit representatives to clarify and confirm certain questions and answers during a visit made to each country.

The structured interviews and questionnaire consisted of questions on different aspects of OHS, for example, legislation, OHS and quality management policy, stakeholders, monitoring, inspection and evaluation of OHS, financing of OHS, integration of OHS, planning and implementation of OHS and quality management, promotion of OHS and quality management, indicators of effectiveness, efficiency, training, and multidisciplinary functions.

Obviously, for the Republic of Moldova, it is appropriate to compare the development of occupational health services with the countries of Eastern Europe and the post-Soviet States. This paper may present arguments for organizing a study for Moldova's neighboring countries: Romania, Hungary, Slovenia, Slovakia, Czech Republic, Bulgaria, and Ukraine.

\section{Results}

In this article, the discussions will target the implementation and development of ILO Convention no. 161 (1985) concerning basic occupational health services among European countries. The BOHS assignments and obligations are employers, employees and their assignee guidance in maintaining a healthy environment that facilitates mental and physical health in relation to work, guidance in workplace accommodation to the worker. BOHS convention stresses the importance of multidisciplinary and multispectral collaboration (ILO, 1985).

The multispectral approach of the concept "occupational health" enquires policy expansion and implementation on all levels in Ministry of Health, Ministry of Labor, Social Protection, and Family and the Ministry of Economy (Husman, 1999). According to the Convention no. 161 (1985), chapter II, Article 5, the functions of occupational health services are (ILO, 1985):

- identification and assessment of the risks and health hazards of the employee at the workplace;

- surveillance of the factors in the working environment and working practices which may affect workers' health, including sanitary installations, canteens, and housing where these facilities are provided by the employer;

- advice on planning and organization of work, including the design of workplaces, on the choice, maintenance and condition of machinery and other equipment and on substances used in work;

- $\quad$ participation in the development of programs for the improvement of working practices as well as testing and evaluation of health aspects of new equipment;

- advice on occupational health, safety and hygiene and on ergonomics and individual and collective protective equipment; 
- surveillance of workers' health in relation to work;

- promoting the adaptation of work to the worker;

- contribution to measures of vocational rehabilitation;

- collaboration in providing information, training and education in the fields of occupational health and hygiene and ergonomics;

- organizing first aid and emergency treatment;

- participation in analysis of occupational accidents and occupational diseases (ILO, 1985).

Among first countries in the European Union that have ratified the ILO Convention no. 161 were: Sweden (1986), Finland (1987), Hungary (1988), Croatia (1991), Macedonia (1991), Slovenia (1992), Czech Republic (1993), Slovakia (1993), Bosnia and Herzegovina (1993), Germany (1994). Obviously, Eastern Europe countries were not analyzed in this study.

According to each country's specificity, national laws establish occupational health services. Ratification at national level allows for the next "step"- implementation in each branch of the national economy (at big, medium and small enterprises level).

The legislative structure of OHS varies greatly in the mentioned countries. For example, Germany has a relatively detailed legislative structure of OHS complemented by lower-level regulations and divided into two parts: 1) technical measures as security of dangerous equipment, and protection against work environment risks; 2) social measures, as reducing of working hours for specially protected groups (young mothers, people with disability). In Sweden and Finland, it is a liberal approach without any limitations.

That is why employers and employee assignees at the organization level elaborate the OHS patterns for accessibility and financing (Ahonen, 1999).

Another position is the OHS subordination. So,

- In Germany, the Federal Ministry of Labour and Social Affairs is the key institution of management and control. The basic document is "The act of Security and Work Health";

- In Sweden, the responsible institution is the Ministry of Labour, Family and Social Affairs and Equal Opportunities. The basic document is "The law of work environment";

- In Finland, the main institutions are the Ministry of Social Affairs and Health and Ministry of Labour. The basic documents are "The Occupational Health Service Act", "The Labour Security Act", "The Labour protection and affair act".

On the other side, the development of the National Strategy and National Policy in the domain of OHS is also important. For OHS to be resistant a substructure is needed. For a good structure, a step-by-step strategy is recommended. Every country should analyze the actuality of OHS to develop its own National Strategy and Activity Program. The pioneer countries that ratified Convention no 161 (1985):

- Germany elaborated the OHS National strategy;

- Finland after the implementation period made a re-evaluation and adopted a proper OHS strategy;

- Sweden has not yet elaborated its own OHS strategy.

According to the interpretation of the legislation, the objectives in 17 European countries can be divided into four categories:

- Comprehensive objectives, including risk assessment and prevention, the promotion of health and well-being, including curative care: Finland, Italy (universities and the 
National Sanitary System do curative care - teaching hospitals); day hospitals and outpatients are present in the hospital unit of occupational health, environmental investigations are carried out by the Regional Agency for Environmental Prevention;

- Comprehensive objectives, including risk prevention, the promotion of health and wellbeing excluding curative care: Austria (curative care is not designated by law, but out of the minimum time provided by law curative care is theoretically possible as long as the employee pays for it and not the social insurance system), Belgium, Denmark, Germany, The Netherlands, Norway, Sweden and Switzerland (occupational health and safety measures based on risk assessment);

- Prevention and protection oriented objectives: France, Greece, Luxembourg, Portugal, Spain and Ireland;

- OHS assist employers to provide curative care excluded by legislation: France, Germany, Portugal (can be on a contractual basis, however).

Note: Germany, France, and Portugal can be included in 2 categories.

Germany - Occupational safety and health services aim to protect the life of people at work and their capacity to work and to preserve a humane work environment. Employers have an obligation to protect the health and safety of workers and provide medical attendance by a company physician.

France - OHS are preventive and aim to monitor the health of workers and adapt workplace according to physiological and psychological requirements, notably industrial hygiene and risks of contagion. OHS must conduct workplace surveillance and advise the employer on improvements. All employees must have annual medical check-ups and follow-ups of occupational diseases or injuries. OHS must produce an annual action plan on work environment covering risks, jobs, and working conditions.

Portugal - Services of safety, hygiene, and occupational health should be oriented towards establishing and managing working conditions, safeguarding the mental and physical health of workers, providing technical prevention, training, and information to workers and promoting the participation of employers and employees.

Finland - The objectives of OHS are a healthy and safe work environment, a wellfunctioning work environment, the prevention of occupational diseases and the promotion and maintenance of work and functional ability.

Italy - Every private and public company must protect workers' health. Employers are obligated to protect the health and safety of their workers and provide medical attendance by an authorized company physician. OHS must conduct workplace surveillance and advise employer on improvements. 
Figure 1. Model - scheme of occupational health services development in Finland.

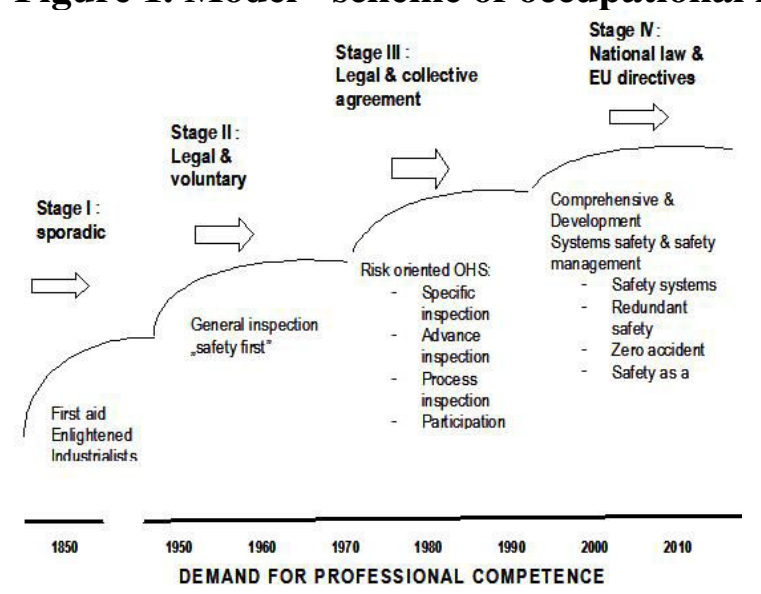

Source: Rantanen J. Evolution of occupational health services in Finland, Työterveyslääkäri, 1998, 1:4-9. countries:

OHS are organized according to some national legislative particularities of 17 European

- Training people in the domain of OHS: Austria, Belgium, Denmark, Finland, Germany, Greece, Italy, Holland, Portugal, Spain, Switzerland.

- Qualification, time management, and faculties: Austria, France, Germany, Denmark, Germany, and Switzerland.

- Specific OHS goals: Austria, Belgium, Denmark, Finland, Germany, Greece, Italy, Holland, Norway, Luxemburg.

- The quality management of OHS legislation: Denmark, Holland, Norway, Finland (for example, the declaration for continue quality development).

- No legislative rules for quality OHS management: Sweden, United Kingdom.

- Organizational patterns for OHS: Belgium, Finland, Holland, France, Denmark.

The organization of OHS patterns and its financing differ in according to the country, because of various historical methods in the occupational health system and economic development of the countries.

In Figure no. 1 is represented a schematic model of the occupational health services development in Finland. Finnish and Italian occupational health services have complete objectives, with risk assessment and prevention, strengthening health workers, with the involvement of curative and preventive services at the workplace (Rantanen, Lehtinen, 1999; Rapas, 2010; Pisla, Bahnarel, Ferdohleb, 2014).

Occupational health services can be strengthened by following steps (Menckel, 1993; Libert, et al., 1998; Felszeghi, 2014; Kim, R., et al., 2014).

I stage - Beginner services (Beg. OHS), which is a reasonable starting point for the progressive development of workplaces and workers. This form of service enables the employment of nurses and primary health care workers from workplace inspectors who are trained in OHS field. The objective is to prevent and control occupational risks and hazards to health and lives of employees.

II stage - Basic Services (B OHS) are based on the infrastructure of health service localized in the workplace geographically closer. The provision of services may vary depending on the company and community needs. Staff in the BOHS consists of doctor and medical assistant specialists in medicine / occupational health. 
III stage - International standardized services (IS OHS) are based on provisions of ILO Convention 161 (1985) ratification with minimum requirements of OHS objectives for each country. Service infrastructure has several optional forms; the aim is mainly preventive, international standard curative services can be provided to workers. Occupational Health Unit with the multidisciplinary team (public or private MSI) is headed by the occupational health specialist doctor and accredited according to the requirements of EC / ILO / WHO (Rantanen, 1999; Rapas, 2010; Pisla, Bahnarel, Ferdohleb, 2014).

IV stage - Multiple specialized services (MS OHS) are usually implemented on large enterprises in industrialized countries and/or they may be provided by multiple specialized health centers. Employees of the multidisciplinary team are physicians-specialists in occupational health, ergonomists, occupational health assistants, psychologists, security engineers, etc. Service structure is represented by specialists for complete coverage of the relevant aspects of occupational health.

Beginner OHS and Basic OHS are found in developing countries - at small and very small enterprises level, for non-formal sectors and the self-employed population that cannot start immediately OHS at the international standard. The considerable growth of the necessity and urgency of implementing the OHS in developing countries were expressed by ILO and WHO concerning basic occupational health services in order to improve the overall coverage of the OHS with reasonable costs, methods and technologies available for small businesses, non-formal employers, patented employees, self-employers (Rantanen, 1999).

Table 1. The actors involved in financing occupational health services.

\begin{tabular}{|l|l|l|l|l|l|l|}
\hline & Country: & State & Employers & $\begin{array}{c}\text { Trade } \\
\text { unions }\end{array}$ & $\begin{array}{c}\text { Public social } \\
\text { security } \\
\text { agencies }\end{array}$ & $\begin{array}{c}\text { Insurance } \\
\text { companies }\end{array}$ \\
\hline 1. & Austria & & & & & \\
\hline 2. & Belgium & & & & & \\
\hline 3. & Finland & & & & & \\
\hline 4. & Germany & & & & & \\
\hline 5. & Italy & & & & & \\
\hline 6. & Portugal & & & & & \\
\hline 7. & Sweden & & & & & \\
\hline 8. & Switzerland & & & & & \\
\hline
\end{tabular}

The rules are used to calculate the number of hours needed for occupational health input from each group) per 1000 employees:

The Austrian Association of Occupational Health Physicians recommends a certain amount for the hourly rate of occupational health physicians; generally speaking, the market regulates the remuneration. For enterprises with less than 50 employees, the Austrian Accident Insurance Board provides OHS free of charge. In those with more than 50 employees, a physician should spend at least approximately 40 minutes/employee/a year (there are precise specifications depending on the number of employees). In the enterprises with less than 50 employees, regular inspections by OHS are needed every year. In the enterprises with less than 11 employees, one inspection every two years and additional inspections on particular occasions are required (accidents at work, new work procedures, new agents, etc.).

Belgium - minimum prices per year are imposed by the federal government in order to avoid market mechanisms which would decrease the quality of service for external services: workers 
with special risks, workers submitted to compulsory examination for risks from visual display units and manual lifting tasks, workers without special risks and thus not submitted to periodic medical examinations.

Finnish occupational health services - funding is directly based on the market price. The Social Insurance Institute reimburses up to $50 \%$ of costs; separate compensation is provided for preventive and curative care.

France - from one to a monthly number of hours of services to enterprises from OHS is required; one-third of that time should be used in the company.

Luxembourg- the semi-public National Occupational Health Services can charge not more than $0.2 \%$ of the total salary mass to employers. The other occupational health services are functioning according to a market-based price.

Germany - 0.1-1.2 hours/insured person is required depending on the basic risk potential; special regulations exist for small and middle- sized enterprises in some insurance companies.

In many cases, these schemes are more useful for large companies than for small and middle-sized enterprises because of the market prices.

Italy, Greece, Ireland, the Netherlands, Norway, Portugal, Spain, and Sweden funding is directly based on the market price.

ILO Convention no. 161 (1985) recommends, according to national background and practices, the following organizational models of occupational health services:

- OHS integrated within companies / institutions (internal);

- OHS covering more companies / institutions (consort);

- Private medical institutions, which offer OHS;

- Public medical institutions, which offer OHS;

- OHS - private-public partnership;

- Public social security institution.

Table 2. Occupational Health Services Models used in some EU countries.

\begin{tabular}{|c|c|c|c|c|c|c|}
\hline & & Finland & Germany & Sweden & Italy & France \\
\hline 1. & $\begin{array}{l}\text { Integrated "built in" OHS - } \\
\text { internal service }\end{array}$ & & & & & \\
\hline 2. & $\begin{array}{l}\text { Joint OHS with different } \\
\text { companies }\end{array}$ & & & & & \\
\hline 3. & $\begin{array}{l}\text { Private medical institutions, } \\
\text { which offer OHS }\end{array}$ & & & & & \\
\hline 4. & $\begin{array}{l}\text { OHS specialized for certain } \\
\text { groups of workers }\end{array}$ & & & & & \\
\hline 5. & $\begin{array}{l}\text { Public medical institutions, } \\
\text { which offer OHS }\end{array}$ & & & & & \\
\hline 6. & $\begin{array}{l}\text { Health care centers proving } \\
\text { OHS }\end{array}$ & & & & & \\
\hline 7. & State OHS for its employees & & & & & \\
\hline 8. & $\begin{array}{l}\text { Company doctor (full or part- } \\
\text { time) }\end{array}$ & & & & & \\
\hline 9. & $\begin{array}{l}\text { OHS provided by statutory } \\
\text { industrial accident insurance }\end{array}$ & & & & & \\
\hline
\end{tabular}




\begin{tabular}{|l|l|l|l|l|l|l|}
\hline & funds & & & & & \\
\hline 10. & Defense medical service & & & & & \\
\hline 11. & $\begin{array}{l}\text { Local authorities providing } \\
\text { OHS }\end{array}$ & & & & & \\
\hline
\end{tabular}

From the mentioned points and international experience, occupational health services structure must be multidisciplinary and multi-specialized. Membership and number of service personnel will be determined by the volume of needs issued by them (Chu, et. al., 2000).

German law requires occupational health services to be provided by specialists in occupational health and those in occupational safety (labor inspection engineers). Specialists in the field and qualified employees from specified area, described in ILO Convention no. 161(1985), are employed when necessary in enterprises / large companies in case of service extension and forming a consortium. Swedish National Board of Occupational Safety and Health plans to encourage a multidisciplinary approach by a system of internal audit of enterprises. In Finland, occupational health specialists are licensed hygienists-physicians, nurses, and physiotherapists who have been specially trained to work in the field. Also, this service involves ergonomics experts, psychologists, and social workers, who obtained training and knowledge in the field. Requirements for the OHS specialists are described in the Decision of the State Council regarding occupational health services.

ILO Convention no. 161 (1985) stipulates that professional independence of employees in occupational health services and the exclusion of any manipulation by the employer is a vital activity. In Finland, there is legislation that supports the independence of occupational health specialists against employers, employees, and their representatives. In the same time, there are also some shortcomings to this topic. "Occupational Safety and Health Act" in Germany mentions the independence of OHS structure. Occupational health services Company in Sweden supported by legislation and promoted by the International Labor Organization - Swedish office will maintain itself independent from operators.

Worldwide, only 32 countries have ratified the ILO Convention no. 161 (1985) concerning occupational health services. Since 1999 in Moldova we have accumulated arguments in favor of ratification of this document and development of occupational health services in line with recommendations of the International Labor Organization and World Health Organization. In Table 3 are listed the countries that ratified the convention.

Table 3. States that ratified the International Labor Organization Convention no. 161 (1985).

\begin{tabular}{|l|l|l|l|l|l|}
\hline No. & Countries: & $\begin{array}{l}\text { Date of } \\
\text { ratification }\end{array}$ & No. & Countries: & $\begin{array}{l}\text { Date of } \\
\text { ratification }\end{array}$ \\
\hline 1. & Sweden & 01.07 .1986 & 17. & Benin & 10.11 .1998 \\
\hline 2. & Mexico & 17.02 .1987 & 18. & Chile & 30.09 .1999 \\
\hline 3. & Finland & 27.04 .1987 & 19. & Serbia & 24.11 .2000 \\
\hline 4. & Hungary & 24.02 .1988 & 20. & Colombia & 25.01 .2001 \\
\hline 5. & San Marino & 19.04 .1988 & 21. & Antigua and Barbuda & 16.09 .2002 \\
\hline 6. & Uruguay & 05.09 .1988 & 22. & Zimbabwe & 09.04 .2003 \\
\hline 7. & Guatemala & 18.04 .1989 & 23. & Poland & 15.09 .2004 \\
\hline 8. & Brazil & 18.05 .1990 & 24. & Turkey & 22.04 .2005 \\
\hline 9. & Croatia & 08.10 .1991 & 25. & Seychelles & 28.10 .2005 \\
\hline 10. & The former Yugoslav & 17.11 .1991 & 26. & Montenegro & 03.06 .2006 \\
\hline
\end{tabular}




\begin{tabular}{|l|l|l|l|l|l|}
\hline 11. & Slovenia & 29.05 .1992 & 27. & Luxemburg & 08.04 .2008 \\
\hline 12. & Czech Republic & 01.01 .1993 & 28. & Niger & 19.02 .2009 \\
\hline 13. & Slovakia & 01.01 .1993 & 29. & Ukraine & 17.06 .2010 \\
\hline 14. & Bosnia and Herzegovina & 02.06 .1993 & 30. & Belgium & 28.02 .2011 \\
\hline 15. & Germany & 17.10 .1994 & 31. & Bulgaria & 01.05 .2012 \\
\hline 16. & Burkina Faso & 25.09 .1997 & 32. & Gabon & 28.07 .2015 \\
\hline
\end{tabular}

On the other hand, in the scientific laboratory of Occupational Health from the National Center for Public Health the concept of Occupational Health Medicine (currently Occupational Health Services) was developed, but failed to be viable because of the considerable changes in health system financing (introduction of compulsory medical insurance) and the professional profiles of the republic (liquidation of large enterprises and increasing number of small / very small ones).

Occupational Medicine is recognized as a clinical and pre-clinical system. The multiclinical character consists in the interference of general pathological consequences of working and work conditions with all clinical specialties (pneumology, internal medicine, neurology, psychiatry, hematology etc.) and preclinical (biochemistry, physiology, genetics, hygiene, epidemiology, etc.).

Occupational medicine being by excellence a dynamic compartment insists on the update of its configuration. It is dynamic from the point of development and diversification of industrial type of production, an aspect which enlarges the etiological background of occupational diseases, and also the progress of biology and medicine, especially in the field of genetics, immunology, immunopathology, imagistic, etc. (Cocarla, 2009; Toma, 2006).

Occupational medicine is a borderline medical specialty, with pronounced multidisciplinary character, and socially strongly linked. It is a difficult specialty, mainly preventive, often pretechnique and with exact terms from the field of physiology, pathology, legislation, etc. (Pauncu, 2014). One-third of our life unfolds at the workplace, and the work conditions have a big impact on the employees' health. All professionals from the health services field should know the causality relation between health and work and that between work and health (Pauncu, 2014).

The society and technical progress are in continuous dynamics, obliging specialty doctors to adapt to new conditions. The volume and quality of knowledge with which future specialists need to be familiarized can be taught in an attractive way, combining classic and modern teaching techniques (Pauncu, 2014).

In the Republic of Moldova, the Reforms of Occupational Health Services/harmonization of the Convention and Directives by UE, WHO, IOM are justified by the following numbers:

- 21.9 thousands of workplaces do not correspond to sanitary-hygienic requirements;

- $27.8 \%$ occupations implies hard physical work;

- the incidence of diagnosis of professional morbidity - 1.65 of 100 thousands of employees, 1.82 times lower than the average of this indicator in 27 EU countries.

From these arguments, in 1999, the scientific laboratory of "Occupational health" of the National Centre of Public Health, in the frame of the results of the state project "Study of the efficiency of the sanitary supervision in work hygiene and of the professional pathologies service, in 1997-1998", which encouraged to start the project "Conception of the Occupational Health Service" first variant - June 3, 1999, next - December 18, 2002 and the third in 2004 receiving positive claims from all persons from occupational medicine services.

Unfortunately, this variant did not have political support, which was explained through the adoption of other afferent normative acts during these years with the precise objective to regulate the 
activities of National Company of Insurances in Medicine (http://lex.justice.md/index.php?action=view\&view=doc\&lang=1\&id=296962).

\section{Conclusions}

Basic Occupational Health Services are listed in the WHO objectives, announced at AlmaAta - WHO Global Strategy on Occupational Health for All.

A wide variation is prevalent among legal basis, scope, coverage, basic guidance, content, and resources available in occupational health services to Finland, Germany, and Sweden. However, functionally OHS development actions are oriented in parallel directions: occupational risk prevention, health promotion, providing curative care, vocational rehabilitation. It is very important to initiate and continue the process of ratification and implementing the ILO Convention no. 161 (1985). These will facilitate the development of occupational health services within the institutions and enterprises, both public and private as in all the branches of Moldavian economic activity.

Some aspects of ratification and implementation of this document are worth mentioning here:

- Political aspect: Ratification of the ILO Convention no. 161 (1985) will help promote Moldova's image as a democratic state that guarantees access to quality occupational health services for all employed persons.

- Normative aspect: The provisions of the ILO Convention no. 161 (1985) concerning occupational health services are compatible with international legal instruments and not contrary to national law.

- Organizational aspect: Responsible for implementation of ILO Convention no. 161 (1985) concerning occupational health services are the Ministry of Health \& the Ministry of Labor, Social Protection, and Family.

- Financial aspect: In order to achieve the ILO Convention goals, the financial resources available in the general government will be used, the partial contribution of employers under the legislation in force and the insurer (if applicable), including official assistance provided by external partners for development.

- Economic aspect: Ratification of Convention no. 161(1985), will help to improve employee health indicators, and indirectly, will facilitate increasing levels of socioeconomic development at national level.

- State Supervisory Board of Public Health, under the Ministry of Health, will identify, assess and monitor risk factors in the occupational environment, will propose measures for occupational illnesses prevention and will supervise the health status of persons subject to action occupational risk factors.

\section{Bibliography}

1. Ahonen, G., 1999. Economic aspects of the work life in transition. American Journal of Industrial Medicine, Suppl 1, pp. 15-16.

2. Chu, C., Breucker, G., Harris, N., et. al., 2000. Health-promoting workplaces - international settings development. Health promotion international, 15(2), pp. 155-167.

3. Cocârlă, A., 2009. Medicina Ocupaţională. Cluj-Napoca: Ed. Medicală Universitară „Iuliu Haţieganu", vol. 1 \& 2.

4. Felszeghi, S., 2014. Principalele aspecte practice ale reglementării medicinii ocupaţionale din Ungaria. Sănătate publică, economie şi management în medicină, 54(3), pp. 11-14. 
5. Friptuleac, Gr., et. al., 2014. Probleme actuale ale sănătăţii ocupaţionale în Republica Moldova. Sănătate publică, economie şi management în medicină, 54(3), pp. 8-10.

6. Husman, K., 1999. General principles and implementation in OHS evaluation. In: E. Menckel, P. Westerholm, eds. Evaluation in occupational health practice. Oxford, ButterworthHeinemann. pp. 8-19

7. Husman, K., Lamberg, M., 1999. Good occupational health service practice. American Journal of Industrial Medicine, pp. 44-46.

8. Iachim, V., Bebîh, V., 2014. Crearea și dezvoltarea serviciului Medicina muncii - una dintre prioritățile politicii sociale. Sănătate Publică, Economie şi Management în Medicină, 54(3), pp. 14-16.

9. Ilmarinen, J., 1999. Aging workers in the European Union. Status and promotion of work ability, employability, and employment. Helsinki: Finnish Institute of Occupational Health and Ministry of Social Affairs and Health, Ministry of Labour.

10. Walters, D., 1996. Health and Safety strategies in Europe. Journal of Loss Prevention in the Process Industries. Elsevier, Volume 9. Issue 5, pp. 297-356.

11. Kim, R., et al., 2014. Occupational health and safety. In: Rechel B, McKee M, eds. Facets of public health. Maidenhead: Open University Pres, pp. 233-254.

12. Libert, B., Yamada, Y., 1998. Occupational medicine in France: a perspective at the 15 th anniversary of Medecine du Travail. Occup. Health, 40, pp. 91-95.

13. Menckel, E., 1993. Evaluating and Promoting Change in Occupational Health Services. Models and applications. Stockholm: Arbetsmilj*ofonden.

14. Morariu, S., Morariu, A., Morariu, V., 2010. Lacune legislative în Medicina Muncii II, Studia Universitatis, Arad: Vasile Goldis University Press.

15. Pauncu, E.A., et. al., 2014. Învăţământul de medicina muncii din Timişoara în perspectiva viitorului specialităţii. Sănătate publică, economie şi management în medicină, 54(3), pp. 2124.

16. Pisla, M., Bahnarel, I., Ferdohleb, A., 2014. Experienţa şi bunele practici ale ţărilor Uniunii Europene în domeniul fortificării serviciilor de sănătate ocupaţională. Sănătate Publică, Economie şi Management în Medicină, 54(3), pp. 24-29.

17. Popescu, F.G., Pauncu, E.A., Nica C., 2015. Clinicile de Medicina Muncii: trecut, prezent, viitor. Arad: EdituraVasileGoldis University Press.

18. Rantanen, J., 2009. From Alma Ata to BOHS. Asian-Pacific Newsletter on Occupational Health and Safety, 16(2), pp. 27 [online] Available at: http://www.ttl.fi/en/publications/electronic_journals/asian_pacific_newsletter/archives/Docume nts/asian_pacific_nl2_2009.pdf [Accessed 24 December, 2015].

19. Rantanen, J. and Lehtinen, S. eds., 1999. Country Reports of the Preparatory Consultation for the International Symposium On Occupational Health For Europeans by organizers. Series: People at Work Research Reports (Volume 29). Helsinki: Finnish Institute of Occupational Health.

20. Rantanen, J.. New concept in occupational health services - BOHS. [online] Available at: http://www.ttl.fi/en/publications/Electronic_publications/Challenges_to_occupational_health_se rvices/Documents/New_conceptin.pdf [Accessed 24 October, 2014].

21. Rapas, L., 2010. Occupational medicine and restructuring - Interoperability Model for the Occupational Health Professionals. Revista Romană de Medicina Muncii, 61(1-2), pp. 43-47.

22. Smits, P., Braeckman, L., Dijk F., Gehanno J.F., Pauncu E.A., Popescu F., Hanna M., Bulat P., 2012. What every doctor know about work and health: a needs analysis in six European countries. 30th International congress on Occupational Health: Occupational health for all: 
from research to practice. Cancún, Mexico, 18-23 March 2012. [online] Available at: https://biblio.ugent.be/publication/4243018 [Accessed 20 October, 2015].

23. Toma, I., 2006. Medicina muncii. Craiova: Sitech., p. 824.

24. Walters, D. ed, 1996. The Identification and Assessment of Occupational Health and Safety Strategies in Europe. Vol. 1: The National Situations. Dublin: European Foundation for the Improvement of Living and Working Conditions. Available at: http://bookshop.europa.eu/ro/the-identification-and-assessment-of-occupational-health-andsafety-strategies-in-europe-pbSY9496930/downloads/SY-94-96-930-EN-

C/SY9496930ENC_001.pdf;pgid=y8dIS7GUWMdSR0EAlMEUUsWb0000sblNkHrF;sid=UF2 dvP1TSSmdqK5Nq1YDG592HT6Dzl-

QLA0=?FileName=SY9496930ENC_001.pdf\&SKU=SY9496930ENC_PDF\&CatalogueNumb er=SY-94-96-930-EN-C [Accessed: 21 October, 2015]

25. ***FIOH - Finnish Institute of Occupational Health, 2001. Survey of the Quality and Effectiveness of Occupational Health services in the European Union and Norway and Switzerland. Helsinki, p. 250.

26. ***ILO - International Labour Organization, 1985. Convention no. 161 on Occupational Health Services. [online] Available at: http://www.ilo.org/dyn/normlex/en/f?p=NORMLEXPUB:12100:0::NO::P12100_INSTRUMEN T_ID:312306 [Accessed: 23 October, 2015]

27.***ILO, 1985. Recommendations no. 171 on Occupational Health Services 1985 [online] Available http://www.ilo.org/dyn/normlex/en/f?p=NORMLEXPUB:12100:0::NO::P12100_INSTRUMEN T_ID:312509 [Accessed: 23 October, 2015]

28. *** WHO Regional Office for Europe, 2013. Health 2020. European policy framework and strategy for the 21 century. pp. 1-184.

29. *** WHO Regional Office for Europe, 2002. Good practices in occupational health services: A Contribution to workplace health.

- *** WHO, 2010. Healthy workplaces: a model for action: for employers, workers, policymakers and practioners [online] Available at: 〈http://www.who.int/occupational_health/publications/healthy_workplaces_model.pdf> [Accessed 30 October, 2014]. 